\title{
カオリン触媒を用いる二価フェノールおよびナフトールの メタノールによる気相エーテル化反応
}

\author{
(1985 年 5 月 22 日 受理)
}

\author{
松 崎武彦* 大須賀 清・杉 義弘・高味康雄・今村寿一
}

\section{1 緒言}

フェノール類と低級アルコール類とを固体酸または固体塩基を 触媒に用いて気相で反応させるとC-アルキルフェノール類が生 成することは古くから知られており ${ }^{1) 21}$ ，近年，熱硬化性樹脂原 料の合成を目的として研究も盛んに行なわれてきだ 8)。この 応は, 固体酸上では, 直接の $C$-アルキル化のほかに, フェニルェ ーテル中間体を経由する経路も存在すると考えられ ルミナなどの固体酸触媒を用いて $C$-アルキルフェノール合成を 目的とする研究において，多くの場合エーテル化合物の副生が認 められている(1) ル類の選択的合成を目的とした研究については，1〜2 の特許 ${ }^{97}$ 除いては報告されていない。

エーテル中間体を経由する経路は，反応温度が低いか，あるい は酸強度の弱い固体酸を触煤に用いる場合に有利であると考克ら れ8)，また，エーテル中間体の転位反応を抑制する条件も同じで あると思われるので, 適当な固体酸を触媒に選び, 比校的低温で フェノール類とアルコール類を反応させることにより，フェニル エーテル類を高収率で合成することは可能と思われる。

著者らは, p-クレゾールとメタノールから p-メトキシトルェ ンの選択的合成を目的として, 多くの固体酸について触媒効果を 検討した結果, カオリンがとくに高い活性と選択性をもつことを 見たした ${ }^{10)}$ 。さらに，このカオリン触媒は他の多くの一価フェ

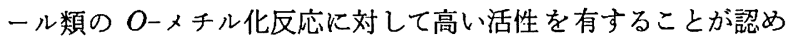
られた ${ }^{10)}$ 。カオリンは，比較的弱い固体酸性を有する粘土鉱物と

化学技術研究所, 305 茨城県筑波郡谷田部町東

1) N. M. Cullnane, S. J. Chard, J. Chem. Soc., 1945, 821.

2）太田暢人, 工化, 51, 143(1948).

3）小方芳郎, 坂西勝正, 細井秀成, 工化, 72, 1102(1969).

4) 井上正美，榎本三郎，石油誌，15，372(1972).

5）西崎忠夫, 田部浩三, 触媒, 14, 138(1972).

6) T. Kotanigawa, M. Yamamoto, K. Shimokawa, Y. Yoshida, Bull. Chem. Soc. Jpn., 44, 1961(1971).

7) 西崎忠夫, 田部浩三, 触媒, 15, 94(1973).

8) 小谷川 毅, 石油誌, 17, 286(1974).

9）長井繁喜，吉田 浩，井上辉比古(宇部尖産)，日特公 昭 53-35062(1978)；梅村純郎, 高光永明, 吉田 浩, 半上烟 比古, 池沢晴三(宇部興産), 日特公 昭 55-6618(1980); 梅村純郎, 高光永明, 吉田 浩, 井上辉比古(宇部與産), 日特公 昭 56-24655(1981).

10）今村寿一, 鬼沢一広, 日特公 昭 56-25213; T. Matsuzaki, K. Kizawa, Y. Sugi, J. Imamura, Chem. Ind., inpress.
して知られているが, Benesi の研究によれば, シリカアルミナな どにくらべて強い酸点をむたず，かつ酸強度の分布が比較的一様 である ${ }^{11)}$

本報告では，このカオリン触媒を二価フェノール類やナフトー ル類のメタノールによる $ー$ メチ化反応に対して適応した結果 について報告する。なお，フェニルェーテル類は，医薬，染料， 香料などの有機中間体および酸化防止剤などの特殊薬品として広 く利用されており，工業的にはもっばらフェノール類を原料と し, 硫酸シメチルなどをメチル化剤とする液相法により合成され ている。しかし, 取り扱い上打よび量産化に対し, 気相接触法が より有利であると思われる。

\section{2 実験}

カオリンは, 共立割業原料(株)提供の朝鮮カオリン (A-6, 水 練固型化品）から調製したつぎの A， B 2 種類を用いた。 $\mathrm{A}$ ：水 練押出成型したもの。径 $3 \mathrm{~mm}$, 長さ約 $5 \mathrm{~mm}, 30 \mathrm{ml}$ 容は約 29 $\mathrm{g}$ 。 $\mathrm{B}$ : そのまま 8〜24 メッシュに粉砕したもの。 $30 \mathrm{ml}$ 容は約 $23 \mathrm{~g}$ 。

反応は, 内径 $22 \mathrm{~mm}$ の硬質ガラス製反応管に触媒 $30 \mathrm{ml}$ を充 填し, 反応温度で 20 分間公素を流したのち, 窒素の供給を止め, メタノールに溶解させた試料をマイクロフィーダーで滴下させ

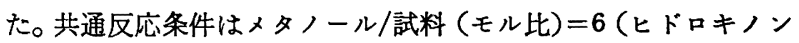
の場合のみ 8 ), LHSV は $0.26 / \mathrm{h}$ である。反応開始後 2 時間経過 後の 3 時間分の反応物を捕集し, 原料フェノール類またはナフト ール類とそのエーテル化合物および $C$-メチル化誘導体について, アセチル化したのちガスクロマトグラフ（カラム充填浏はChromosorb-W-AW-DMCS）で定量を行なった。ここで反応率は供 給したフェノール,ナフトール類の減少率で表わし, 生成物収率 は供給したフェノール, ナフトール類に対する生成モル比で, ま た，選択率は反応したフェノール，ナフトール類に対する生成モ ル比で表わした。

\section{3 結果と考察}

\section{1 ヒドロキノンの $\boldsymbol{O}$-メチル化反応}

カオリン Aを用い, ヒドロキノン (HQ) とメタノールの反応 に対する反応温度の影響を図 1 に示す。 $250^{\circ} \mathrm{C}$ のとき, $\mathrm{HQ}$ 反応 率 $80 \%, \mathrm{HQ}$ のモノェーテル体 (HME) とジェーテル体 (HDE) とを合わせた選択率は $90 \%$ を越え, カオリンが実用触媒として

11) H. A. Benesi, J. Phys. Chem., 61, 970(1957); J. Am. Chem. Soc., 78, 5490(1956). 


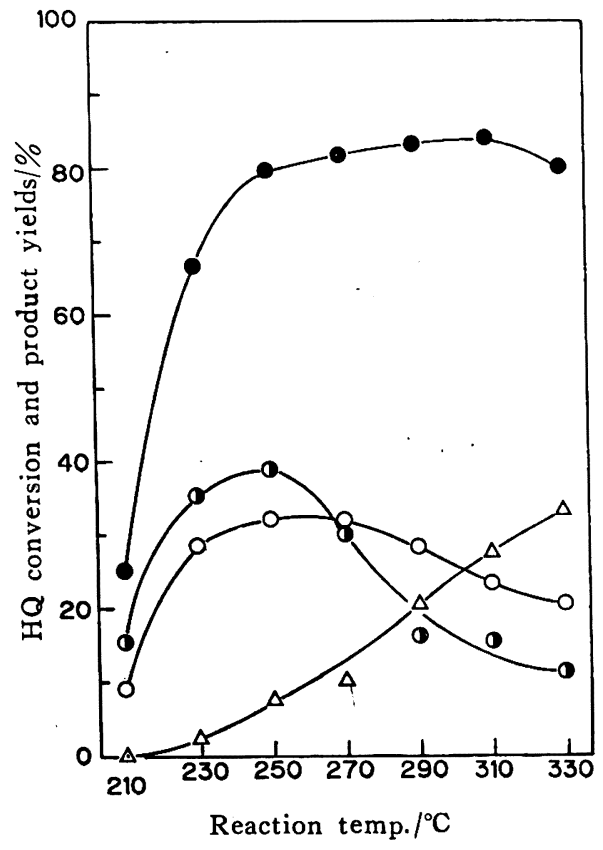

Fig. 1 Effect of reaction temperature for $O$-methylation of hydroquinone (HQ) with methanol on kaolin-A

Reaction conditions; $\mathrm{CH}_{3} \mathrm{OH} / \mathrm{HQ}=8$ (mole ratio), LHSV $0.26 / \mathrm{h}$ Symbls :

; Conversion of $\mathrm{HQ}$ yield of

( ) Hydroquinone dimethylether (HDE)

$\mathrm{O}$; Hydroquinone monomethyl ether (HME)

$\triangle ; C$-Methylated derivatives

十分な活性と選択性を有することが認められた。 $250^{\circ} \mathrm{C}$ 以上では 逆反応との平衡により反応率は一定となった。また，高温となる にしたがい,ェーテル体の収率が減少し，それとともにCーメチル 化反応が促進された。このさい, $\mathrm{HQ}$ と HME のC-メチル化体 は温度上昇とともに急增したか，HDEのCーメチル化体はほぼー

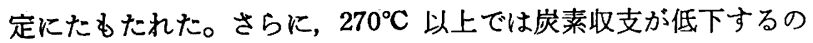
で,クラッキンクやや重合などの副反応が盛んになると思われる。 高温での HDE の減少がとくに大きいのは, HMEのC-メチル化 転位やその他の副反応が，HME $\longrightarrow \mathrm{HDE}$ の反応にくらべて早 くなるほかに, HDE 自体の $C$-メチル化転位やその他の副反応が 顕著になるためと考学られる。

このカオリンの, $230^{\circ} \mathrm{C}$ に护ける活性の経時変化を図 2 に示 す。活性は時間とともに低下し，24 時間後には $\mathrm{HQ}$ の反応率は 約半分となった。カオリンを $230^{\circ} \mathrm{C}$ で 24 時間焼成してから反応 に用いた場合の初期活性を図 2 中に示したが，この結果は暁成し ない触媒の初期活性とほとんど変わらなかったので，活性劣化は 熱的な要因によるるのではない。同じオリンを一価フェノール 類の $O$-メチル化反応汇用いた場合には長時間 (800 時間以上) 活 性変化は認められなかった10)。 $\mathrm{HQ}$ の O-メチル化反応の場合に は, 一価〉ェノール類にくらべて $\mathrm{HQ}$ やその生成物の沸点が高 いのでこれらが触媒表面上に付着しやすく，また，そのためこれ らの分解あるいは重合生成物が 沈着しやすいためと思われる。

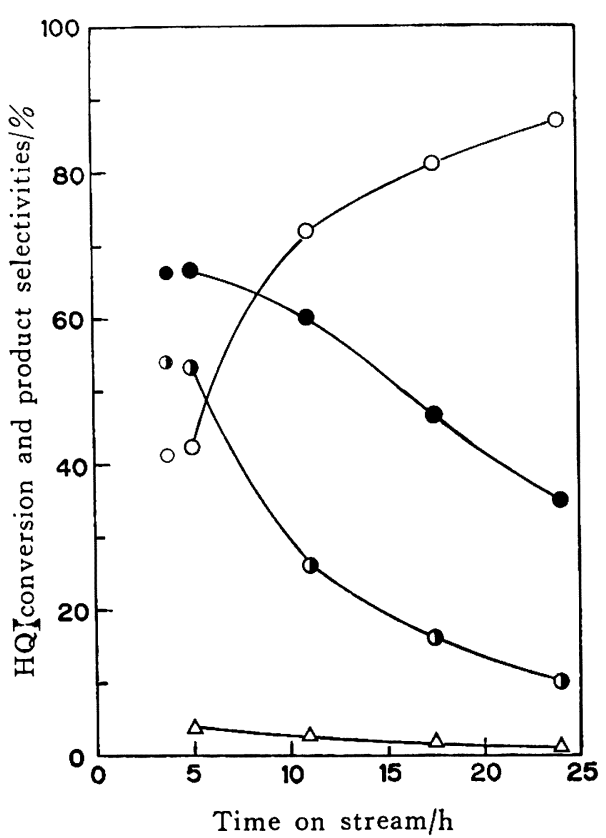

Fig. 2 Effect of continuous reaction time for $O$-methy. lation of hydroquinone(HQ) with methanol on kaolin-A

Reaction conditions :

$\mathrm{CH}_{3} \mathrm{OH} / \mathrm{HQ}=8$ (mole ratio), LHSV $0.26 / \mathrm{h}$

Symbols :

; Conversion of $\mathrm{HQ}$

Selectivity of

- $\mathrm{HDE}, \mathrm{O}$; HME,

$\triangle ; C$-Methylated derivatives

(Small symbol : Kaolin-A had been calcined in

$\mathrm{N}_{2}$ at $230^{\circ} \mathrm{C}$ for $24 \mathrm{~h}$ before reaction)

なお，触媒の劣化により $\mathrm{HQ} \longrightarrow \mathrm{HME}$ の反応は低下するが， $\mathrm{HME} \longrightarrow \mathrm{HDE}$ の反応の低下がそれ以上に大きく，また副生物 である O-メチル化体の生成る減少するので，HME の収率や選 択率はむしろ向上する結果となった。

つぎ，カオリンBを窒素中で焼成（3時間）して用いた場合 の烧成温度の影響を図 3 亿示す。カオリンの活性は $300^{\circ} \mathrm{C}$ で㹸成 した場合に最大となり，450 $\mathrm{C}$ 以上では活性の低下が大きくなっ た。この間 BET 表面積は 30〜35 $\mathrm{m}^{2} / \mathrm{g}$ とほとんど変わらず，活 性との直接の関係はないと思われる。また，この触媒の空気流通 下に淤る TG および DTA 分析結果を図 4 亿示したが, $100^{\circ} \mathrm{C}$ 付近の付着水の脱離のほか, $500^{\circ} \mathrm{C}$ 付近火構造水の脱離によると 思われる変化が認められた。触媒中の構造ヒドロキシル基量の尺 度として, 四 3 中に赤外スペクトルによる $3960 \mathrm{~cm}^{-1}$ 付近の吸収 強度を示したが，燃成温度に対するその強度変化は活性の変化と

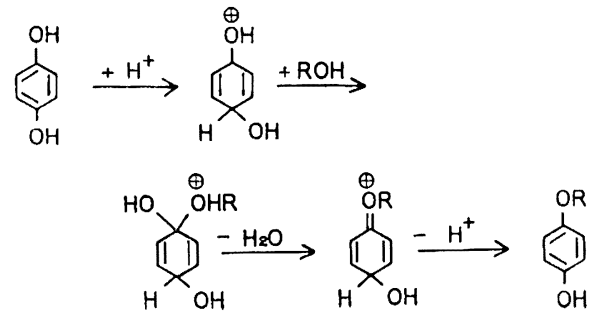




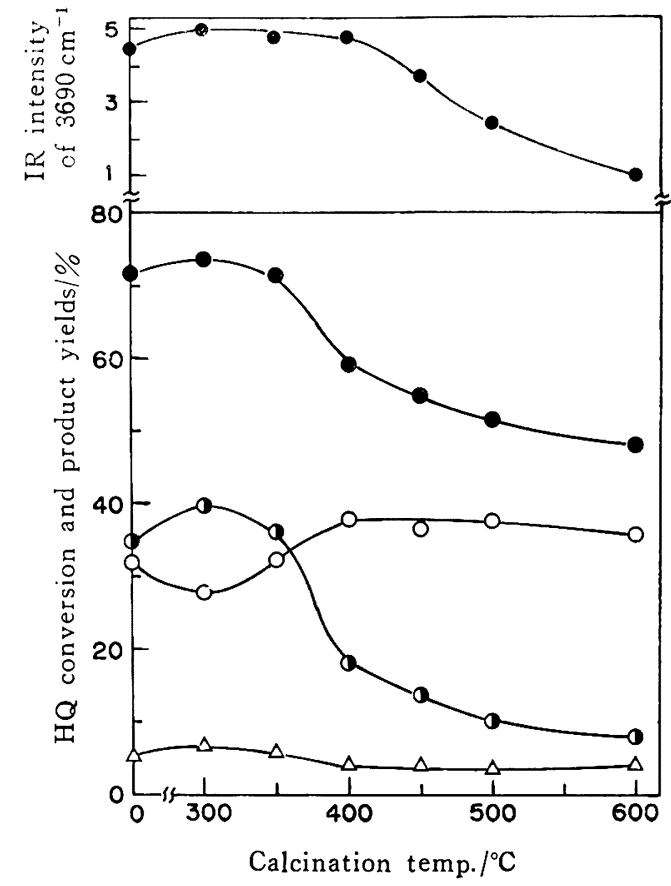

Fig. 3 Effect of calcination temperature of kaolin-B for $O$-methylation of hydroquinone with methanol and relative IR intensity of essential $\mathrm{OH}$ group

Reaction conditions :

$\mathrm{CH}_{3} \mathrm{OH} / \mathrm{HQ}=8$ (mole ratio), LHSV $0.26 / \mathrm{h}$

Symbols :

; Conversion of $\mathrm{HQ}$

Yield of

; HDE, O ; HME,

$\triangle ; C$-Methylated derivatives

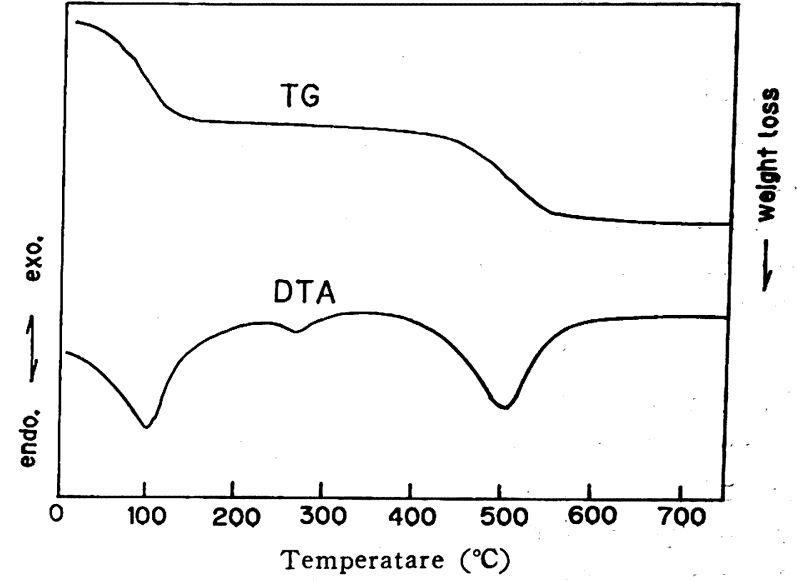

Fig. 4 DTA and TG profils of kaolin-B Heating rate $12.5^{\circ} \mathrm{C} / \mathrm{min}$, in air flow

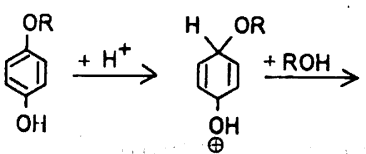

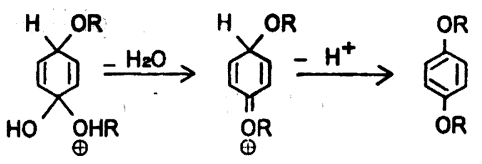

よく一致した。これらの結果から、ェーテル体生成の主反応で は,プロトン酸点の関与するつぎのような芳香族求核置換反応機 構で進行することが推定される。

前に述べた，反応時間に対する活性贫化は，触媒上への炭素質 の沈着によるプロトン酸点の減少によると考えられる。また，高 温烧成による活性劣化も, 反応時閒による活性劣化の場合と同様

Table $1 O$-Methylation of phenols and naphthols with methanol over kaolin

\begin{tabular}{|c|c|c|c|c|c|c|}
\hline \multirow[b]{2}{*}{ Reactant } & \multirow{2}{*}{$\begin{array}{l}\text { Temp. } \\
\left({ }^{\circ} \mathrm{C}\right)\end{array}$} & \multirow{2}{*}{$\begin{array}{l}\text { Conv. of } \\
\text { reactant } \\
(\%)\end{array}$} & \multicolumn{3}{|c|}{ Product selectivity (\%) } & \multirow{2}{*}{$\begin{array}{l}\text { Calcination } \\
\text { temp. of } \\
\text { kaolin }\left({ }^{\circ} \mathrm{C}\right)\end{array}$} \\
\hline & & & $\begin{array}{l}\text { Dimethyl } \\
\text { ether }\end{array}$ & $\begin{array}{c}\text { Monomethyl } \\
\text { ether }\end{array}$ & $\begin{array}{l}\text { By- } \\
\text { products }^{a)}\end{array}$ & \\
\hline Catechol & 250 & 18.1 & 0 & 100 & 0 & Uncalcined \\
\hline$" \prime$ & 290 & 30.9 & 0 & 79.6 & 13. 8 & "I \\
\hline$" \prime$ & 320 & 31.7 & 0 & 71.1 & 28.5 & $" \prime$ \\
\hline$\prime \prime$ & 290 & 37.1 & 0 & 78. 2 & 19.2 & 450 \\
\hline Resorcinol & 290 & 24.8 & 0.8 & 39.4 & 62.5 & Uncalcined \\
\hline " & 250 & 27.4 & 0.9 & 48. 7 & 48.7 & 450 \\
\hline$" \prime$ & 290 & 41.6 & 1.2 & 35.9 & 62.1 & 450 \\
\hline " & 320 & 55.2 & 1.1 & 26.3 & 68.2 & 450 \\
\hline $\mathrm{RME}^{b)}$ & 290 & 56.1 & 20.7 & $30.3^{c)}$ & 42.4 & Uncalcined \\
\hline 2-Naphthol & 290 & 90.6 & - & 28. 3 & 71.5 & " \\
\hline " & 290 & 79.0 & - & 40.0 & 51.5 & 500 \\
\hline$\prime \prime$ & 290 & 81.2 & - & 41.6 & 52.5 & 600 \\
\hline 1-Naphthol & 290 & 55.5 & - & 42.7 & 24.6 & 600 \\
\hline " & 320 & 67.3 & - & 27.3 & 34.3 & 600 \\
\hline
\end{tabular}

Reaction conditions; Reactant/Methanol $=1 / 6$ (mole ratio), Catalyst : Kaolin-B $30 \mathrm{~m} l$ $(23 \mathrm{~g})$, LHSV $0.26 / \mathrm{h}$.

a) C-Methylated compounds.

b) Resorcinol monomethyl ether.

c) Resorcinol. 
に（1)式にくらべて(2)式の影響が大きく, C-ィチル化活性も 低下するので, HDE の収率低下が大きく, HME の収率はむし ろ增大することになった。

3.2 カテコール, レソルシノール, ナフトールの 0 -メチル 化反応

カテコール (CA), レソルシノール (RE), 1-および2-ナフト ール (1-, 2-NA) とメタノールの反応結果をまとめて表 1 に示

す。触媒としてはカオリン $\mathrm{B}$ (焼成および未焼成)を用いた。

$\mathrm{CA}$ と RE の O-メチル化は, $\mathrm{HQ}$.の場合よりも高温を必要と しまたジェーテルをほとんど生成しなかったが，HQ の場合と 異なり,カオリンを $450^{\circ} \mathrm{C}$ で焼成することにより活性が向上し た。これは、フェノールの種類により最適酸性度が異なるからで あろら。焼成により $O$-メチル化体選択率はわずかに低下するが, CA については $290^{\circ} \mathrm{C}$ のときにモノェーテル選択率約 $80 \%$ が得 られた。なお，このさいジェーテルが生成しないのは立体障害に よるものであろう。RE の場合はとくにC-メチル化体（ほとんど 2,4-位のメチルレソルシノール) の生成がいちじるしく，エーテ
ル選択率は小さかった。これは，ヒドロキシル基のオルトーパラ 配向性によると思わ机る。また， RE からのジェーテル体生成は 少なかったが，モノェーテル体とメタノールとを反応させるとジ エーテルと RE を生成した。

NA のOーメチル化の埸命，カオリンを铌成することにより活 性は低下したが，エーテル体の選択率は向上した。プロトン酸性 の減少により NA からの直接の $C$-メチル化が低下したためと思 われる。この結果は, 酸性度の高いほど $C$-メチル化に有利である とした Klemm らの結果 ${ }^{12)}$ と一致する。またこの結果は，NAの

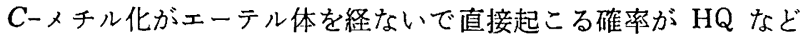
の場合よりも高いことを示している。なお，2-NA について， $600^{\circ} \mathrm{C}$ で焼成したカオリンを用い，反応を 12 時間継続して行な っても活性や選択率に变化はなかった。この結果は, 高温㹸成し たカオリンは長時間使用してもそれ以上の酸性度の減少がないこ とを示している。

12) J. H. Klemm, J. Shabtai, D. R. Taylor, J. Org. Chem., 33, 1480(1968).

\title{
Vapor Phase Synthesis of Methyl Ethers of Dihydric Phenols and Naphthols with Methanol Catalyzed by Kaolin
}

\author{
Takehiko Matsuzaki*, Kiyoshi Ohsuga, Yoshihiro Sugi, Yasuo Takami \\ and Juichi Imamura
}

\author{
National Chemical Laboratory for Industry, Tsukuba Research Center; \\ Yatabe, Ibaraki 305 Japan
}

Catalytic effects of kaolin on the synthesis of methyl ethers of hydroquinone, catechol, resorcinol, 1- and 2-naphthols with methanol were studied in vapor phase at $210 \sim 330^{\circ} \mathrm{C}$. Mono- and dimethyl ethers of hydroquinone were produced in high yield at $230 \sim 250^{\circ} \mathrm{C}$, whereas dimethyl ether was decreased at high temperature with increasing by-products: $\boldsymbol{C}$-methylated derivatives and others. Calcination of kaolin at high temperature diminished the conversion of hydroquinone to ethers, which corresponded to the decrease of hydroxyl group of kaolin. The reaction seems to proceed over protonic acid sites by nucleophilic substitution mechanism.

For other phenols and naphthols, the $O$-methylation required higher temperature. Catechol gave only monomethyl ether with the selectivity of $80 \%$ at $290^{\circ} \mathrm{C}$. However, resorcinol and naphthols gave predominantly $C$-methylated derivatives. The calcination of kaolin promoted the catalyst activity for catechol and resorcinol, or increased the selectivity of ethers for naphthols. 